УДК $811.111-26$

DOI https://doi.org/10.26661/2414-1135-2021-83-21

\title{
ПОНЯТІЙНИЙ СКЛАДНИК КОНЦЕПТУ ПОЛІТИКА В СТРУКТУРІ СУЧАСНОЇ АНГЛІЙСЬКОМОВНОЇ КАРТИНИ СВІТУ
}

\author{
Курбатова Т. В. \\ кандидат філологічних наук, дочент, \\ дочент кафедри іноземних мов \\ Криворізький національний університет \\ вул. Віталія Матусевича, 11, Кривий Ріг, Дніпропетровська область, Украӥна \\ orcid.org/0000-0001-6891-443X \\ kurbatova@knu.edu.ua \\ Ліхошерст О. Г. \\ викладач кафедри іноземних мов \\ Криворізький національний університет \\ вул. Віталія Матусевича, 11, Кривий Ріг, Дніпропетровська область, Україна \\ orcid.org/0000-0002-5245-9724 \\ olgalihoserst@knu.edu.ua
}

Ключові слова: кониепт, політика, дефініція, картина світу, понятійний складник.
У статті досліджена лінгвокогнітивна структура понятійного складника концепту ПОЛІТИКА в сучасній англомовній картині світу. Політика одна 3 найважливіших сфер буття людини та суспільства. Як одиниця картинування свідомості вонапредставляє індивідуальний досвідлюдини, а також досвід усього суспільства, відбиваючи явища політичного життя в свідомості носіїв мови. Серед основних завдань у цій роботі визначаємо аналіз дефініцій мовних реперезентантів концепту в англомовних словниках з метою виокремлення понятійного складника та інтерпретації змісту концепту. Для досягнення цієї мети використовувалися методи дефініційного та компонентного аналізу. Об'єктом дослідження виступає концепт ПОЛІТИКА в сучасній англійськомовній картині світу. Предметом дослідження $\epsilon$ структура понятійного складника концепту. Матеріалом дослідження виступають мовні одиниці, що репрезентують концепт ПОЛІТИКА. Дослідження проводилось із застосуванням комплексної методики концептуального аналізу. Це дозволило визначити основні уявлення про політику як такі, що зафіксовані у семантиці мовних одиниць, співвіднесених із політичною сферою діяльності носіїв сучасної англійської мови. Абстрактний характер цього поняття спричинює існування декількох лексичних одиниць, які активізують різні за змістом аспекти - politics, policy, political, politician, які утворюють ядерну зону концепту. У периферійній зоні знаходяться такі одиниці, як роwer, government, political activity, science, party, organization, state, country, leader, politician, the UN, globalization, crisis, human rights, global society, які конкретизують це поняття та виражають його різноманітні аспекти. Структура понятійного шару концепту ПОЛІТИКА характеризується високою лексико-семантичною щільністю. Це викликано абстрактним характером поняття, що є одним з базових в світосприйнятті людини. 


\title{
NOTIONAL COMPONENT OF THE CONCEPT POLITICS WITHIN THE MODERN ENGLISH-SPEAKING WORLDVIEW
}

\author{
Kurbatova T. V. \\ Candidate of Philological Sciences, Associate Professor, \\ Associate Professor at the Department of Foreign Languages \\ Kryvyi Rih National University \\ Vitalii Matusevych str., 11, Kryvyi Rih, Dnipropetrovsk region, Ukraine \\ orcid.org/0000-0001-6891-443X \\ kurbatova@knu.edu.ua \\ Likhosherst O. H. \\ Lecturer at the Department of Foreign Languages \\ Kryvyi Rih National University \\ Vitalii Matusevych str., 11, Kryvyi Rih, Dnipropetrovsk region, Ukraine \\ orcid.org/0000-0002-5245-9724 \\ olgalihoserst@knu.edu.ua
}

Key words: concept, politics, definition, worldview, notional component.

\begin{abstract}
The article researches into lingual and cognitive structure of the notional component of the concept POLITICS within the modern English-speaking worldview. Politics is one of the most important fields of human and society's being. It is an open multisided unit of human cognition, which is in constant motion of forming its own content and is realized in multiple situations of communication. Being a unit of cognitive mapping, on the one hand, it embodies one's personal experience, and, on the other hand, the experience of the whole community that reflects political phenomena in speakers' minds. The research paper is aimed at analyzing definitions of linguistic representatives of the concept by studying English dictionaries and encyclopedias. This is done to single out the notional component and interpret the concept's content. To achieve this goal, methods of definitional and component analysis are used. The concept POLITICS in the modern English-speaking worldview is the research object, while the structure of its notional component is the subject of our research. This enables to determine basic ideas about politics fixed in semantics of language units related to the political sphere of modern English speakers. According to lexicographic sources, the lexeme politics started functioning in the English language in the 14th century. In spite of its many synonyms, the nomen politics reflects the content of the notional component of the studied concept to the fullest. The abstract nature of this notion conditions appearance of several lexical units that form the nuclear zone of the concept - politics, policy, political, politician. Power, government, political activity, science, party, organization, state, country, leader, politician, the UN, globalization, crisis, human rights, global society and numerous other units form the periphery of the concept as they make the notion of politics more detailed and express its various aspects. The structure of the notional layer of the concept POLITICS is characterized by high nominative density, which is conditioned by its abstract and universal nature.
\end{abstract}

Постановка проблеми. Процеси сприйняття, категоризації та концептуалізації навколишньої реальності людиною починаються 3 осмислення нею явищ зовнішнього середовища, його об'єктів та 3 визначенням місця мовця в системі об'єктів. У результаті цієї когнітивної діяльності в свідомості людини з'являються концепти. У контексті сучасних проблем когнітивної лінгвістики особлива увага приділяється концептуальній репрезентації знань в мовній картині світу, основною одиницею якої є концепт. Концепт визначається як ментальне утворення, яке включає в себе поняття, значення та 
образ, які описують певний фрагмент оточуючого середовища [1]. Хоча концепт базується на таких семіотично пов'язаних категоріях, як значення та поняття, він $є$ значно ширшим за них.

Мовні засоби, пов'язані з об'єктивацією основних аспектів і понять людського існування, викликають постійний інтерес дослідників [2-5]. Концепти як ментальні утворення формують концептуальну картину світу з огляду на те, що вона $\epsilon$ результатом пізнання дійсності, тобто когніції. Таку картину світу людина формує в процесі його пізнання [6]. Сучасна лінгвістика надає таке визначення: «Мовна картина світу - це система взаємопов'язаних мовних одиниць, що відбиває об'єктивний стан речей довкілля і внутрішнього світу людини. Якщо концептуальна картина світу існує у вигляді концептів, що утворюють концептосферу, то мовна картина світу існує у вигляді значень мовних знаків, які утворюють сукупний семантичний простір мови» [7, с. 15].

Політика - одна 3 найважливіших сфер буття людини та суспільства. В якості одиниці картинування свідомості, з одного боку, вона представляе індивідуальний досвід людини, а з іншого - досвід усього суспільства в цілому, відображаючи явища політичного життя в свідомості носіїв мови. Це відкрита і багатогранна одиниця людської свідомості, яка постійно формує свій зміст, реалізуючись у різноманітних ситуаціях спілкування. Як засіб організації та регулювання людських відносин політика не має собі рівних, бо вона уособлює весь досвід розвитку людської цивілізації та своїми прогностичними рисами завжди націлена на майбутнє. Саме тому актуальним $є$ вивчення концепту ПОЛІТИКА та засобів його репрезентації в сучасній англійській мові.

Метою статті $\epsilon$ дослідження структури концепту ПОЛІТИКА в англійськомовній картині світу. Серед основних завдань у цій роботі визначаємо аналіз дефініцій мовних реперезентантів концепту ПОЛІТИКА в англомовних словниках 3 метою виокремлення понятійної складової та інтерпретації змісту концепту. Для досягнення цієї мети використовувалися методи дефініційного та компонентного аналізів.

Об'сктом дослідження виступає концепт ПОЛІТИКА в сучасній англійськомовній картині світу. Предметом дослідження $є$ структура понятійного складника концепту ПОЛІТИКА в англійськомовній картині світу. Матеріалом дослідження виступають мовні одиниці, що репрезентують англійськомовний концепт ПОЛІТИКА.

Виклад основного матеріалу дослідження. Виходячи з тези про те, що понятійний компонент концепту ПОЛІТИКА детермінується політичним дискурсом, який виступає реалізацією політич- ної свідомості, у роботі проаналізовано дефініції ключової лексеми-номену концепту politics та iï основних синонімів в англомовних словниках та енциклопедіях.

Політика $є$ одним 3 найбільш неоднозначних термінів. У повсякденному сенсі політикою називають будь-яку цілеспрямовану діяльність, а саме: мистецтво управління суспільством, громадську активність, сферу задоволення амбіційних потреб індивіда тощо. Саме тому і в науковій картині світу існують різні тлумачення цього складного явища. Зазвичай під політикою (від грецького politika державні або громадські справи) розуміють соціальну діяльність у політичній сфері суспільства, спрямовану на досягнення, утримання та реалізацію влади [8]. Поняття polis (місто-держава, особлива форма політичної та соціально-економічної організації суспільства в Давній Греції та Давньому Римі) було одним 3 фундаментальних в античній, а пізніше і в європейській філософії, етиці, історії, а згодом дало початок політичній науці. Зміст поняття включав разом 3 державним управлінням, державним правом, обов'язком, діяльністю, справою також такі семантичні елементи, як громада, суспільство, громадянин.

Згідно 3 лексикографічними джерелами в англійській мові лексема politics почала функціонувати з XIV століття [9]. Абстрактний характер цього поняття спричинює існування декількох лексичних одиниць, які активізують різні за змістом аспекти.

Лексема politics реалізується у більшій кількості лінгвістичних контекстів завдяки своїй полісемантичності та поліфункціональності. Аналіз словникових статей виявив такі дефініції концепту ПОЛІТИКА, politics: 1) наука та мистецтво управління; наука, яка займається формами, організацією та управлінням державою та відносинами 3 іншими державами - the practice or study of the art and science of forming, directing, and administrating states and other political units; the art and science of government; political science; 2) комплекс взаємовідносин людей у суспільстві, особливо відносин, що передбачають маніпуляції з владою - ії захоплення, підтримку, втрату, зміцнення тощо - the complex or aggregate of relationships of people in society, esp those relationships involving authority or power; 3) політичні дії, події, практики (в цьому значенні синонім до лексеми policy) - political activities or affairs; 4) сфера діяльності людини, професія - the business or profession of politics; 5) діяльність, пов'язана 3 владою широкому сенсі, контролем над іншою особистістю, ситуацією - any activity concerned with the acquisition of power, gaining one's own ends, etc.; 6) відношення, принципи, переконання, симпатії, антипатії, які викликає політика в свідомості індивіда чи 
групи індивідів (партія, прихильники) - opinions, principles, sympathies, etc.; 7) а) діяльність уряду по розробці політичного курсу/стратегіï - the policyformulating aspects of government as distinguished from the administrative, or legal; b) діяльність держави в соціальній сфері - the civil functions of government as distinguished from the military [9].

Macmillan Dictionary приводить такі тлумачення зазначеної лексеми:

1) the ideas and activities involved in getting power in a country or over a particular area of the world (e.g. Many people feel that their interests are not represented by mainstream politics); 2) the profession of being a politician (e.g. He entered politics at the age of 21);3) the ideas and activities used by people within a particular group to try to get power (e.g. Now that I am self-employed, I don't worry about office politics); 4) your politics are your beliefs and attitudes about how government should work (e.g. Her politics became more conservative as she grew older); 5) the study of how people gain and use political power (e.g. a degree in politics); 6) the use by someone of particular ideas to try to get what they want (e.g. The party is trying to exploit the politics of class envy) [10].

Аналіз дефініцій з International Encyclopedia of Political Science [11] показує, яким чином формується поняттєвий складник концепту в науковій картині світу:

1) політика як особлива сфера діяльності: "If politics is everywhere around the world considered more or less as managing social harmony, it can clearly be conceived as the opposite of some other classical spheres of social action (politics vs. social life, military, administration, etc.)" [11, c. 54];

2) політика як інструмент (досягнення та утримання влади): “...politics is commonly defined as a specific kind of power; either it is held by a central institution, such as a state, a government, a ruling class, or it is used by a power holder who is considered to be legitimate" [11, c. 54];

3) політика як функція: “... politics should be considered as the permanent invention of the polis (city), as the construction of each social unit that aims to keep people together on a permanent basis. This point was already made by Plato, who considered politics as the art of organizing social harmony" $[11$, c. 53].

Отже, лексема politics, що є іменем (номеном) концепту ПОЛІТИКА, що досліджується, у своєму інтегративному значенні трактується як одна зі сфер життєдіяльності суспільства, система певних суспільних відносин, взаємодія класів, націй, держав між собою за допомогою влади, сукупність дій, заходів, установ, за допомогою яких узгоджуються інтереси різних верств населення, прагнення здобуття і використання держав- ної влади, цілеспрямованого впливу на неї, участь у справах держави, у визначенні форм, завдань, змісту іiі діяльності, наміри, мета і способи дій правлячої еліти та ії оточення, прояви хитрощів, обережності, таємничості, ухилянь тощо.

Поняття «політика» вербалізується також за допомогою лексеми policy, яка означає курс дій, прийнятий i дотримуваний владою, керівництвом, політичною партією, політиками, тощо "a course or principle of action adopted or proposed by an organization or individual". Саме у цьому значенні розуміється термін state policy, який може уточнюватися відповідно до певних напрямів international, domestic, economic, social, cultural policy. Близькими за змістом, але не синонімічними є номінації political strategy/programme. Термін public policy може вживатися паралельно у значеннях «державна влада» та «публічна влада». Цей термін протиставляється номену politics, який позначає діяльність і боротьбу традиційних дійових осіб (наприклад, політичних партій, зацікавлених груп, соціальних та політичних рухів), спрямованих на захоплення законодавчої чи урядової влади 3 дотриманням конституційних чи інституційних норм.

Зміст поняттєвого складника концепту ПОЛІТИКА виражений лексичним знаком politics, який виступає як ім'я концепту. Хоча ім'я концепту має досить широкий синонімічний ряд, до якого, крім згаданих, входять statecraft, statesmanship, polity, internal affairs, foreign affairs, campaign, government, governing, control, power, authority та інші концепти, результати номінативного аналізу цих синонімів свідчать про їх відмінність і неможливість цих номінацій слугувати ім'ям концепту ПОЛІТИКА.

Розглянемо особливості синтагматичних зв'язків ядерних номінацій концепту ПОЛІТИКА. Особливо поширеним $є$ вживання терміна policy у сполученні $з$ такими експресивно-оцінними прикметниками, які розкривають образну складову концепту: sound/wise policy, rigid policy, flexible policy, prudent policy тощо. Нерідко сполучення 3 оцінними прикметниками породжує усталені вирази, в яких експресивно-оцінна семантика втрачає свою силу. Проявляється тенденція до фразеологізації в таких виразах: clear/clear-cut policy, big-time policy, local/nationwide policy, global policy/politics, які активують такі ознаки концепту, як якість, гнучкість, динамічність, масштаб. У нетермінологічному сенсі політика постає в значенні діяльності, справи в будь-якій cфepi: monetary/investment/industrial/exchange rate policy.

Синтагматичні зв'язки слова politics в значенні «питання та події суспільного/державного життя» характеризуються сполучуваністю 3 такими 
топонімічними одиницями: Iraq's politics, the politics of Northern Ireland, British politics, які відображають події політичного життя цих країн.

Синтагматичні зв'язки одиниць, що репрезентують концепт ПОЛІТИКА, з дієсловами досить широкі. У результаті предикативної дистрибуції цих номенів вони часто набувають термінологічного або фразеологічного характеру: to adhere to a policy, to conduct/pursue a policy, to advocatelabide by a policy, to go into politics, to talk politics тощо.

Аналіз парадигматичних зв'язків номену концепту передбачає опис його синонімічних зв'язків. Крім згаданих вище одиниць, виявляється велика кількість синонімічних зближень в контекстуальних проявах кожного значення ядерної номінації politics: policy, political organization/management/ administration/system, government, affairs, political actions/events/life, statecraft, statesmanship, polity, internal affairs, foreign affairs, campaign, governing, control, power, authority тощо.

Аналіз структурних деривативних зв'язків іменника politics виявляє його великий словотворчій потенціал, представлений такими деривативами: politic (adj, v), political, politically, politician, politicization, politicize, politick ( $v$, adj), politicker, politicking, politicly, polity, politico, politicoholic, politicone, politicaster, impolitic, apolitical, politicoless, politology, politologist. Прикладами словоскладання можуть слугувати politics-conscience, politics-free, politics-mad, politics-ridden, politico-cultural, politico-religious тощо.

Розширення лексико-семантичних зв'язків демонструє функціонування терміна-деривату political. Особливу увагу звертають на себе моделі сполучення цього прикметника 3 іменниками, які можна розділити на такі семантичні групи: 1) «особа» - political leader / observer / analyst / scientist / man / killer / operator / rival / enemy; 2) «діяльність»-political struggle / killing / rivalry / scandal / support / row / campaign / show / showdown / cooperation / defeat / victory.

Як і номінації politics та policy, прикметник political сполучається з лексичними одиницями на позначення явищ з інших сфер діяльності, особливо зі сфери економіки, що свідчить про нерозривний зв'язок політики та економіки в свідомості людини: political bankruptcy/economy/balance/ broker/market/bargain/capital/inflation/crisis.

Також характерним $є$ поєднання прикметника 3 номінаціями $з$ таких сфер: воєнної справи - political attack / combat / battle / enemy / ally / expansion / surrender / bombshell; екологія - political thaw / forecasting / tide / landscape/ temperature / heat / environment / earthquake; спорту - political game / gambling / pawn; права - political crime / racketeering / killing / suicide / prisoner / police / trial / offense / offender / killer; інших наук - polit- ical orbit / machine / machinery / technology / spectrum / leverage.

Згідно з загальновідомою теорією в когнітивній лінгвістиці прийнято репрезентувати концепт як структуру, що має ядро і периферію. При цьому ядро концепту становлять словникові значення лексеми (план змісту), а периферію - суб'єктивний досвід, різні прагматичні складники лексеми, конотації й асоціації [12]. Аналіз фактичного матеріалу показав, що в свідомості носіїв поняття «політика» пов'язане 3 такими мовними одиницями, як politics, policy, political які утворюють ядро концепту ПОЛІТИКА. На периферії перебувають такі одиниці, як power, government, political activity, science, party, organization, state, country, leader, politician, the UN, globalization, crisis, human rights, global society та багато інших, які конкретизують це поняття у свідомості та виражають його різноманітні аспекти.

Висновки. Отже, структура понятійного шару концепту ПОЛІТИКА характеризується високою лексико-семантичною щільністю, що викликано абстрактним характером поняття, яке є одним з базових в англійськомовній картині світу. Перспективою дослідження $\epsilon$ вивчення лексико-семантичних та структурних характеристик концепту ПОЛІТИКА на основі аналізу номінацій периферійної зони та одиниць вторинної номінації.

\section{ЛITЕРАТУРА}

1. Воркачев С.Г. Счастье как лингвокультурный концепт : монография. М. : Гнозис, 2004. $236 \mathrm{c}$.

2. Бабушкин А.П. Типы концептов в лексико-фразеологической семантике языка. Воронеж : Изд-во ВГУ, 1996. 104 с.

3. Болдырев Н.Н. Когнитивная семантика : курс лекций по английской филологии. Тамбов : Издательство Тамбовского университета, 2000. $123 \mathrm{c}$.

4. Пименова М.В. Введение в когнитивную лингвистику. Кемерово, 2004. Вып. 4. С. 9.

5. Селиванова Е.А. Когнитивная ономасиология : монография. Київ : Фитосоциоцент, 2000. $248 \mathrm{c}$.

6. Попова З.Д., Стернин И. А. Язык и национальная картина мира. Воронеж : Истоки, 2003. $59 \mathrm{c}$.

7. Хрищена О. Поняття мовної та концептуальної картин світу у науці про мову. URL: https:// naub.oa.edu.ua/2012/ponyattya-movnoji-takontseptualnojikartyn-svitu-u-nautsi-pro-movu (дата звернення: 12.08.2021).

8. Политический словарь. URL: http:// mirslovarei.com/content_pol/politika-5.html (дата звернення: 12.08.2021). 
9. Oxford English Dictionary. URL: http:/ www.oxforddictionaries.com (дата звернення: 12.08.2021).

10. Macmillan Dictionary. URL: https://www. macmillandictionary.com/dictionary/british/ politics (дата звернення: 12.08.2021).

11. Badie B. International Encyclopedia of Political Science, SAGE Publications, Inc; 1st edition (September 7, 2011), $4032 \mathrm{p}$.

12. Фрумкина Р.М. Есть ли у современной лингвистики своя эпистемология? Язык и наука кониа XX века. М. : Российский государственный гуманитарный университет, 1995. C. 74-117.

\section{REFERENCES}

1. Vorkachev S.G. (2004) Happiness as a linguocultural concept. Monograph [Schastye kak lingvokulturnyi kontsept. Monografiya]. Moscow: Gnosis.

2. Babushkyn A.P. (1996) Types of concepts in lexical and phraseological semantics of a language [Tipy kontseptov $\mathrm{v}$ leksikofrazeolohycheskoy semantike yazyka]. Voronezh: Yzd-vo VHU.

3. Boldyrev N.N. (2000) Cognitive semantics. Course of lectures in English semantics [Kognitivnaya semantika. Kurs lektsyi po anglyiskoy filologii]. Tambov. Yzdatelstvo Tambovskoho unyversyteta.
4. Pimenova M.V. (2004) Introduction to cognitive linguistics [Vvedenye $\mathrm{v}$ kohnitivnuyu lingvistiku]. Kemerovo, issue 4, p. 9.

5. Selyvanova E.A. (2000) Cognitive onomasiology. Monograph [Kognitivnaya onomasiologiya. Monografiya]. Kyiv: Fitosotsiotsent.

6. Popova Z.D. (2003) Language and the national worldview [Yazyk i natsionalnaya kartina mira]. Voronezh: Ystoky.

7. Khryshchena O. (2012) Poniattia movnoi ta kontseptualnoi kartyn svitu u nautsi pro movu. URL: https://naub.oa.edu.ua/2012/ponyattyamovnoji-ta-kontseptualnojikartyn-svitu-u-nautsipro-movu.

8. Political dictionary [Politicheskyi slovar]. http:// mirslovarei.com/content pol/politika-5.html.

9. Oxford English Dictionary. URL: http:// www.oxforddictionaries.com.

10. Macmillan Dictionary. URL: https://www. macmillandictionary.com/dictionary/british/ politics.

11. Badie B. (2011) International Encyclopedia of Political Science, SAGE Publications, Inc; 1st edition.

12. Frumkina R.M. (1995) Does modern linguistics have its own epistemology? [Yest li u sovremennoy lynhvystyky svoya epistemologyia?]. Yazyk $i$ nauka kontsa XX veka. [Collection of articles]. Moscow, pp. 74-117. 